\title{
THE EFFECT OF MARKETING MIX ON "KPR XTRA BEBAS" DECISION MAKING IN BANK X REGIONAL I
}

\author{
Kevin Michael Arthur ${ }^{1}$, Alla Asmara ${ }^{2}$, Megawati Simanjuntak ${ }^{3 *}$ \\ ${ }^{1}$ Management and Business, School of Business, IPB University, 16151 \\ ${ }^{2}$ Economic Science, Faculty of Economic and Management, IPB University, Bogor, \\ 16680 \\ ${ }^{3}$ Department of Family and Consumer Sciences, Faculty of Human Ecology, IPB \\ University, Bogor, 16680 \\ *Corresponding author: mega_juntak@apps.ipb.ac.id
}

\begin{abstract}
The rapid growth of mortgages affected Bank $X$ to launch product innovation "KPR Xtra Bebas." Realization since the establishment of KPR Xtra Bebas product did not reach the target desired by management. This study aims to analyze factors that influence consumer decision by using KPR Xtra Bebas products in order to do useful and efficient marketing. Sampling procedure used purposive sampling technique as one of the non-probability sampling techniques, namely sampling based on categories that have used the product. Data used are primary data by filling out the questionnaire conducted by the respondents themselves (selfadministered survey). This study used the Partial Least Square (PLS) to analyze results from 94 samples. Results of the study identified the variables of price, place, promotion, and the process did not have a significant influence. While product, human resources, and physical evidence have a significant influence. Managerial implications that are generated are for variables that do not have a significant effect evaluation is needed to determine the appropriate strategy. Companies can build customer databases by implementing cross-selling so that promotional variables can function effectively.
\end{abstract}

Keywords: marketing mix, mortgage product, partial least square analysis, purchase decision.

\begin{abstract}
Abstrak
Perkembangan KPR yang sangat pesat mempengaruhi Bank $X$ untuk meluncurkan inovasi produk KPR Xtra bebas. Realisasi sejak dibentuk produk KPR Xtra bebas tidak mencapai sesuai target yang diinginkan manajemen. Penelitian ini bertujuan untuk menganalisis faktor-faktor yang mempengaruhi keputusan pengambilan produk KPR Xtra bebas agar dilakukanya pemasaran yang efektif dan efisien. Prosedur pengambilan sampel dilakukan dengan teknik purposive sampling merupakan salah satu teknik non probabilitas sampling yaitu penarikan sampel berdasarkan kategori yang sudah menggunakan produk. Data digunakan adalah data primer dengan pengisian kuesioner dilakukan sendiri oleh responden (self administered survey). Penelitian ini menggunakan analisis Partial Least Square (PLS) untuk menganalisis hasil dari 94 sampel. Hasil penelitian menunjukkan variabel harga, tempat, promosi dan proses tidak memiliki pengaruh signifikan terhadap keputusan pengambilan produk KPR Xtra bebas. Sedangkan variabel produk, sumber daya manusia dan bukti fisik memiliki pengaruh signifikan terhadap keputusan pengambilan produk KPR Xtra bebas. Implikasi manajerial yang dihasilkan adalah perlu dilakukan evaluasi untuk dapat menetapkan strategi yang sesuai. Perusahaan dapat membangun customer database dengan menerapkan cross selling sehingga variabel promosi dapat berfungsi efektif.
\end{abstract}

Kata kunci: analisis partial least square, bauran pemasaran, keputusan pengambilan, produk KPR. 


\section{Introduction}

The banking industry is the most needed to fulfill economic life in society. Bank as an industry always tries to figure out the direction of society financial needs development. Therefore sustainable business could be attained in the bank itself. According to Solomon (2013), in order to fulfill consumers need, want, and satisfaction banks always offer their most beneficial product or program. Credit is one of the primary product of the bank. Credit simplify customer in terms of buying the product(s) by installments for a particular period. KPR or Kredit Pemilikan Rumah (House Ownership Credit) is one of the product in which bank industries always proffer. KPR launched as the financial support for the community who unable to buy the house in cash. KPR product became the most preferred product for the customer as the alternative residential property consumption payment in Indonesia as much as 76 percents. The rapid development of KPR is marked by the growth of Bank or financial institution which is offer KPR's product with exciting feature such as low interest and flat in a particular period. Data in which issued by Bank of Indonesia in 2017 showed that there is an increment of the value of outstanding KPR and KPA (Kredit Pemilikan Apartemen/Apartment Ownership Credit) from 2014 to 2016. These data also give information regarding the demand for home ownership in Indonesia.

Diverse of KPR's products available with the exciting features and offer many alternatives for the customer to decide the best KPR for them according to customer's rating and consideration. Customer decision making over KPR's product from a specific bank adjusted with their objective and the benefit. According to Mudrajad (2003), the customer could have taken other alternatives instead of KPR since they have other options. Customer's decision in taking KPR is most important before taking KPR in the bank. The decision has to be made carefully to avoid major or minor obstacles, and also to attain the goals that have been made by the customers. Therefore, the bank industry could state the best offer of KPR's product and have the big opportunity chosen by the customers.

The corporation could see the factors which affected the consumers to engage with credit's facility in order to adjust the best marketing strategy. Mustafa (2012), said that bank interest influences the customer's decision whether to take KPR or not. The fluctuation bank central interest became one of the company's strategies to state their interest in KPR. Steven (2012) stated the stability of the capital market and their equity determine the consumer's confidence to utilize the KPR. Meanwhile, Stephanie and Eesha (2017), said consumers' interested more in the long term loan as their confidence fit in. Hence, the company should see the needs of the consumer from the external factor, in this case, is central bank interest and the internal factor which determined by the consumer's confidence.

The product of "KPR Xtra bebas" is one of the home credits which packed in interestingly way to attract as much as possible consumer to buy the product. According to Arpan (2010), customer's decision in buying KPR influenced by marketing mixes such as product, price, place, promotion, people, physical evidence, and process (7P) and consumer behavior is the environment, individual, and psychological factors. Engel et al. (1995) has been researched the state of awareness and found their awareness still low towards the product, hence need an effective marketing strategy to raise the buy intention. One of the marketing strategies that needed to be considered of the variables in the marketing mix is product strategy, price, place, promotion, process, human 
resources, and physical substation. Through the marketing mix strategy, the company knows what has been done related to the effectiveness of the marketing mix in fulfilling their needs, how much their impact on product's decision making.

\section{Methods}

The research was performed in Jabodetabek (Jakarta, Bogor, Depok, Tangerang, and Bekasi) areas as the regional 1 Bank X Jabodetabek. Jabodetabek was chosen since the rapid growth of KPR's portfolio is higher in this place than other cities. However, the result of this research cannot be generalized to other areas. This research was taken three months from March to May 2018. The sampling procedure used the purposive technique in which belong to non-probability sampling in a certain period (Hartono, 2008). Total of respondents are 94 people. The data collected is primary data from the main source (Ruslan, 1999). Data collection was done by distributing questionnaires based on the limited location which is in regional 1 Jabodetabek. Questionnaire's distribution was done by face to face with the respondents. The questionnaires are a self-administered survey meaning that respondents fill out the form by themselves. The characteristic of respondents was only the customer that engage in KPR Xtra Bebas product.

\section{Variable Measurement}

Variables in this research consist of latent variable and constructor indicator which reflect the latent variable itself. There are 8 latent variables that have been used, i.e., variables of product, price, place, promotion, process, people, and physical evidence also dependent variable is decision making. This research used a questionnaire with a Likert scale as the attribute in data collection. According to Sekaran (2003), Likert scale designed to test the extent of respondent's strength from agreeing to disagree with the statement in 5 scales. This table below shows the definition of each variable that had been used. Each variable and its indicators are given symbols to ease the research.

Table 1 Operational definition and variables indicators

\begin{tabular}{|c|c|c|c|}
\hline $\begin{array}{l}\text { Latent } \\
\text { Variable }\end{array}$ & Operational Definition & Variable Indicators & Symbol \\
\hline $\begin{array}{c}\text { Product } \\
\text { (X1) }\end{array}$ & $\begin{array}{l}\text { The product offered by the company } \\
\text { which will give benefit to consumers, } \\
\text { aside that product should be } \\
\text { competitive enough and have its } \\
\text { appeal. }\end{array}$ & $\begin{array}{l}\text { 1. The product is appropriate to be } \\
\text { marketed } \\
\text { 2. Product provide benefits } \\
\text { 3. Competitive products } \\
\text { 4. Notable products } \\
\text { 5. The flexibility of the installment } \\
\text { date } \\
\text { 6. Products have appeal }\end{array}$ & $\begin{array}{l}\text { PO1 } \\
\text { PO2 } \\
\text { PO3 } \\
\text { PO4 } \\
\text { PO5 } \\
\text { PO6 }\end{array}$ \\
\hline $\begin{array}{l}\text { Price } \\
(\mathrm{X} 2)\end{array}$ & $\begin{array}{l}\text { Price costs incurred by customers to } \\
\text { obtain credit facilities must be } \\
\text { measure rationally; thus the products } \\
\text { can compete with competitors' } \\
\text { products. }\end{array}$ & $\begin{array}{l}\text { 1. Competitive fix interest rates } \\
\text { 2. Competitive floating interest } \\
\text { rates } \\
\text { 3. Provide provision discount } \\
\text { promotions } \\
\text { 4. No appraisal fees } \\
\text { 5. Credit contract fees }\end{array}$ & $\begin{array}{l}\mathrm{H} 1 \\
\mathrm{H} 2 \\
\mathrm{H} 3 \\
\mathrm{H} 4 \\
\mathrm{H} 5\end{array}$ \\
\hline
\end{tabular}




\begin{tabular}{|c|c|c|c|}
\hline $\begin{array}{l}\text { Latent } \\
\text { Variable }\end{array}$ & Operational Definition & Variable Indicators & Symbol \\
\hline $\begin{array}{c}\text { Place } \\
\text { (X3) }\end{array}$ & $\begin{array}{l}\text { Product information, credit process } \\
\text { up to product decision making can be } \\
\text { accessed through the website and } \\
\text { branch office }\end{array}$ & $\begin{array}{l}\text { 1. Access branch offices easily } \\
\text { 2. ATM Networks and branch } \\
\text { offices } \\
\text { 3. Access to information } \\
\text { 4. The branch office is clean and } \\
\text { comfortable }\end{array}$ & $\begin{array}{l}\text { T1 } \\
\text { T2 } \\
\text { T3 } \\
\text { T4 }\end{array}$ \\
\hline $\begin{array}{l}\text { Promotion } \\
\text { (X5) }\end{array}$ & $\begin{array}{l}\text { The company's way to attract } \\
\text { consumers by creating advertising } \\
\text { programs and design. }\end{array}$ & $\begin{array}{l}\text { 1. Attractive advertising } \\
\text { 2. The slogan has appeal } \\
\text { 3. Attractive poster design } \\
\text { 4. Informative product catalog } \\
\text { 5. Information on KPR Xtra Bebas }\end{array}$ & $\begin{array}{l}\text { PR1 } \\
\text { PR2 } \\
\text { PR3 } \\
\text { PR4 } \\
\text { PR5 }\end{array}$ \\
\hline $\begin{array}{l}\text { Process } \\
\text { (X6) }\end{array}$ & $\begin{array}{l}\text { The credit process consists of a credit } \\
\text { analysis process, appraisal process, } \\
\text { credit approval, credit binding, post- } \\
\text { sale service and repayment of } \\
\text { facilities. }\end{array}$ & $\begin{array}{l}\text { 1. Fast credit analysis process } \\
\text { 2. Fast appraisal process } \\
\text { 3. Efficient repayment process } \\
\text { 4. Quick respond customer service } \\
\text { 5. Competitive credit process }\end{array}$ & $\begin{array}{l}\text { PS1 } \\
\text { PS2 } \\
\text { PS3 } \\
\text { PS4 } \\
\text { PS5 } \\
\end{array}$ \\
\hline $\begin{array}{l}\text { Human } \\
\text { Resources } \\
\text { (X7) }\end{array}$ & $\begin{array}{l}\text { Human resources in the discussion of } \\
\text { this research are marketers. The } \\
\text { quality of marketers is measured by } \\
\text { product understanding, ethics, and } \\
\text { appearance. }\end{array}$ & $\begin{array}{l}\text { 1. Marketers dressed according to } \\
\text { SOP } \\
\text { 2. Marketers comprehend the } \\
\text { products } \\
\text { 3. Responsive marketers } \\
\text { 4. Amiable marketers } \\
\text { 5. Marketers do not commit fraud }\end{array}$ & $\begin{array}{l}\text { SM1 } \\
\text { SM2 } \\
\text { SM3 } \\
\text { SM4 } \\
\text { SM5 }\end{array}$ \\
\hline $\begin{array}{l}\text { Physical } \\
\text { Evidence } \\
\text { (X8) }\end{array}$ & $\begin{array}{l}\text { A thing that significantly influences } \\
\text { consumer decisions. Incorporate } \\
\text { companies, corporate achievement, } \\
\text { and awards are indicators of physical } \\
\text { evidence. }\end{array}$ & $\begin{array}{l}\text { 1. Understandable credit's forms } \\
\text { 2. Corporate ignition as an appeal } \\
\text { 3. Corporate awards as an } \\
\text { attraction } \\
\text { 4. Attractive company's logo } \\
\text { 5. Have Tron Videos }\end{array}$ & $\begin{array}{l}\text { BF1 } \\
\text { BF2 } \\
\text { BF3 } \\
\text { BF4 } \\
\text { BF5 }\end{array}$ \\
\hline $\begin{array}{l}\text { Decision } \\
\text { Making } \\
\text { (Y1) }\end{array}$ & $\begin{array}{l}\text { The process by which consumers } \\
\text { provide recommendations, feel the } \\
\text { benefits of the product and are not } \\
\text { affected by the competitors' products. }\end{array}$ & $\begin{array}{l}\text { 1. Providing benefits from all } \\
\text { aspects of credit }\end{array}$ & KP1 \\
\hline
\end{tabular}

\section{Partial Least Square (PLS) Analysis}

PLS is one of the alternative methods of SEM (Structural Equation Modelling) which can be used to subdue the problems and relations. PLS assuming the research data is free of distribution, meaning that research data does not refer to one particular distribution. PLS is an alternative method with a variance-based approach to model prediction-oriented components, whereas the covariance-based SEM method is oriented towards making analysis models and requires a robust theoretical basis of a relationship model. Typical features of SEM with PLS according to Hair et al. (2006) are:

1) SEM with PLS estimates the loading of manifest/indicator variables for exogenous latent variables based on predictions of endogenous latent variables rather than based on variants divided between manifest variables or indicators on the same latent variables as those occurring in covariant-based SEM. Thus loading is a contributor to the path coefficient.

2) SEM with PLS offers acceptable results for measurement models where the relationship of structural models is not significant. 
3) Conceptually the use of SEM with PLS is the same as the use of multiple linear regression, namely maximizing the variance explained in the dependent variable (endogenous latent variables) by adding to assessing the quality of data based on the characteristics of the measurement model.

4) The researchers used SEM with PLS to name the reflective measurement model as model A and the formative measurement model as model B.

5) The SEM path model with PLS is the same as covariant based SEM, which is based on path diagrams from path analysis.

According to Ghozali (2008), there are several things which differentiate the PLS analysis and other SEM analyses models those are:

1) Data does not have to be normally distributed or multivariate.

2) A small number of samples can be used, at least 30 samples.

3) PLS can be used to confirm the theory and explain whether or not there is a relationship between latent variables.

4) PLS can analyze as well as construct formed with reflexive and formative indicators.

5) PLS can estimate large and complex models with hundreds of latent variables and thousands of indicators.

SEM only use PLS to test the relationship model between recursive variables only. Similarly with the path analysis model which is not the same as SEM based on covariance which also allows the occurrence of non-recursive relationships. The workings of PLS can be categorized into three, and the first category is weight estimate to create scores or values of latent variables, second reflects the path estimate which connects latent variables and its indicators (loading), third relates to means and location parameters (value regression constants) for indicators and latent variables. To obtain these three estimates, PLS uses a three-stage iteration process, and each interaction stage produces estimates for the inner model and outer model, the third stage produces an estimate of means and locations (constants).

PLS does not assume a particular distribution for parameter estimation, so parametric techniques to test the significance of parameters are not needed. The PLS evaluation model is based on predictive measurements that have nonparametric properties, then reflexive indicators are evaluated with convergent and discriminant validity from the indicator and composite reliability for the block indicator. The next is an outer model with formative indicators is evaluated based on substantive content by comparing the magnitude of relative weight and seeing the significance of the weight size. PLS developers say that PLS is soft modeling because it can be applied to all data scales, not many require assumptions, and sample sizes do not have to be large. Besides being able to be used to confirm the theory, PLS can also be used to establish relations that have no theoretical basis. Modeling in Path Modeling PLS has two models, which is:

1) Outer Model or measurement model is a measurement model which connect indicator with its latent variables.

2) Inner model or Structural Model, which is a structural model that connects latent variables. According to Chin (1998), a test on a structural model was carried out to examine the relationship between latent constructs. There are several tests for structural models, one of which is R-square endogenous constructs. The R-square value is 0.67 (strong), 0.33 (medium) and 0.19 (weak). 


\section{Findings}

\section{Measurement Model Evaluation}

The measurement model of latent variables to SEM PLS divided into two models, i.e., the reflexive model and formative model. This research used the reflexive, whereas the model is evaluating the indicator reliability, discriminant validity, internal consistency, and convergent validity. Loading factor value is linking the latent variable to its indicators which used to test the validity. This research's loading factor is $>0.5$. Figure 1 shows the final SEM measurement model after doing the first model respecification.

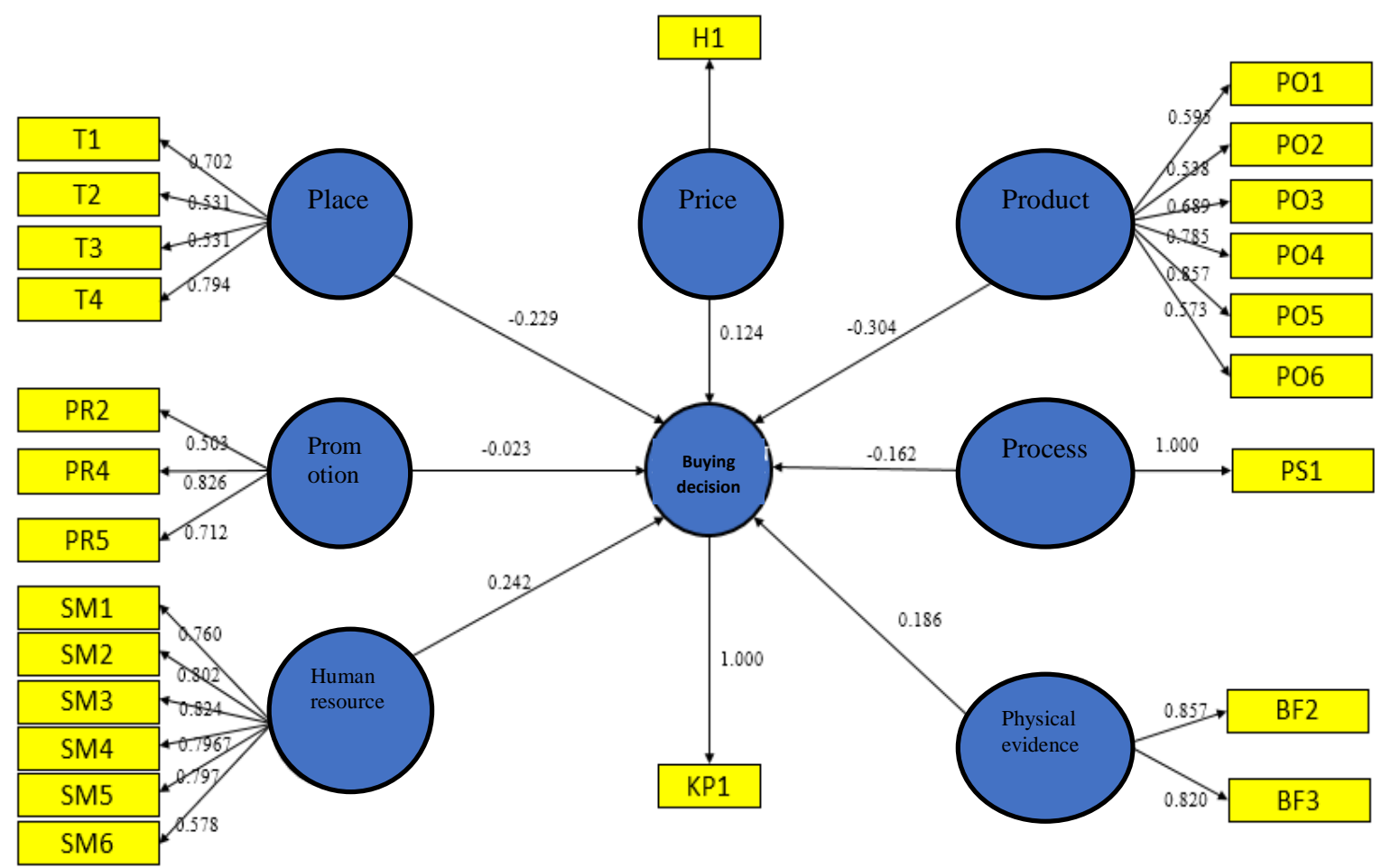

Figure 1 SEM Measurement Model

The first PLS model contains 36 variable indicators $\mathrm{x}$ and one variable indicator Y. The result of model respecification 1 dismiss some indicators to reach only 25 variable indicators $\mathrm{x}$ and one variable indicator $\mathrm{Y}$. As can be seen, the final result of model respecification 1, loading factor $<0.5$ could not be found, meaning the whole indicators in each variable validated. Aside from, loading factor, convergent validity can be seen through the Average Variance Extracted (AVE). The AVE value of all variables is above 0.5 , meaning that convergently the validity of the model can be fulfilled. To ensure that there are no problems related to measurement, the last step in evaluating the outer model is to test the unidimensionality of the model. Unidimensionality test is done by using the composite reliability indicator and Cronbach's alpha. All variables have composite reliability values that are more than 0.7 . This means that if based on composite reliability values there are no problems with reliability or unidimensionality in the model formed. The structural decision making model produces the R-Square value of 0.344 which means it can be seen that the influence of the diversity of product variables, price, place, promotion, physical evidence, process and people on the decision 
making variable is 34.4 percent (Table 2) while other variables can explain the remaining 65.6 percent outside of the research. Other variables do not measure in this research but influence decision making are attitudes toward behaviour, subjective norms, and behavior control (Setiawati et al., 2018).

Table 2 AVE Value, Composite Reliability, Cronbach's Alpha and R-Square

\begin{tabular}{lcccc}
\hline Latent Variables & AVE & $\begin{array}{c}\text { Composite } \\
\text { Reliability }\end{array}$ & $\begin{array}{c}\text { Cronbach's } \\
\text { Alpha }\end{array}$ & R-Square \\
\hline Decision Making & 1.000 & 1.000 & 1.000 & 0.344 \\
Human Resources & 0.584 & 0.893 & 0.863 & \\
Physical Evidence & 0.703 & 0.825 & 0.578 & \\
Place & 0.618 & 0.760 & 0.408 & \\
Price & 1.000 & 1.000 & 1.000 & \\
Process & 1.000 & 1.000 & 1.000 & \\
Product & 0.513 & 0.837 & 0.803 & \\
Promotion & 6.74 & 0.804 & 0.535 & \\
\hline
\end{tabular}

\section{Effect Analysis of Marketing Mix}

The examination of hypotheses was done by bootstrapping on smart PLS, there are three variables have a significant effect on the decision making on KPR Xtra Bebas mortgage and the four variables have no significant influence. The results on the bootstrapping hypotheses can be seen in Table 3. A variable is considered to have a significant effect if the value of t-value is higher (>) than t-table and the value of $p$ value is less than 0.2 . In the table 3 , promotional variables have no influence, while the six influential variables with significance levels vary.

Table 3 The effect of the marketing mix on decision making

\begin{tabular}{lccl}
\hline The effect of latent variables & t values & $p$ values & Conclusion \\
\hline Product -> KPB & 2.122 & 0.034 & Significant \\
Price -> KPB & 1.346 & 0.179 & Not Significant \\
Place -> KPB & 1.584 & 0.113 & Not Significant \\
Promotion -> KPB & 0.203 & 0.839 & Not Significant \\
Process -> KPB & 1.432 & 0.152 & Not Significant \\
Human resources-> KPB & 2.176 & 0.030 & Significant \\
Physical Evidence -> KPB & 2.136 & 0.033 & Significant \\
\hline
\end{tabular}

Examination with the PLS method shows that the product variable has a significant influence on KPR Xtra Bebas decision making. The significance of product variables with a value of $\alpha=5$ percent and the value of $t$-value is more celebrated than $t-$ table. All indicators on the product valid, i.e., marketed product provide benefits, competitive, well-known, flexibility in installment dates and the product has an appeal. The consumers who have taken the KPR Xtra product are free to see the advantages and benefits of the product. Innovations applied by companies with the superiority of declining interest rates have succeeded in attracting consumers.

The price variable in this study discusses the costs incurred by consumers to obtain KPR Xtra Bebas product. The test results show that the price variable has no significant influence on decision making. Indicators of credit costs are not taken into account by consumers to use products. Increasing credit costs will not affect consumers' decisions in lending. Consumers do not take into account the costs incurred in obtaining 
KPR Xtra Bebas product. Consumers are not interested in provisioning discounts, appraisal fees, and credit interest rates as long as the bank approves the facilities submitted by consumers. There is only one indicator that provides consumer appeal, namely the fixed interest rate of KPR Xtra Bebas.

The place variable does not have a significant influence on product decision making. Place variable influence caused by the regulator's policy of encouraging noncash transactions and leaving cash transactions. The policy requires banking companies to limit the expansion of branch offices and utilize digital technology as a media transaction. This is evidenced by indicators on place variables where consumers see more information accessibility, branch office accessibility, and convenience. While the quantity of ATM networks and branch offices is not a concern for consumers to use products.

The promotional strategy implemented by Bank X to increase the growth of Xtra Bebas loans is through Price and Prize War. However, based on the results of the research promotion variables do not have a significant effect on decision making. The results of the study show that the strategies applied were not valid. Implementing advertising, slogan, poster design and product catalog programs is not a consumer attraction. The company needs to change its promotion strategy by utilizing the resources that the company has.

As a financial services company that in its business activities relies on consumers' trust; thus the processes should be considered. The statistical tests show that the process variable has no significant effect. There is only one indicator from the five indicators studied, namely the rapid analysis process. This shows the importance of developing technology infrastructure to support the credit analysis process. Software developed by the company to support process services namely RCS and MAPS is the dominant strategy to support the credit process. Other process indicators, namely appraisal process, repayment process, service process and competitive process compared to other banks have a value of loading factors below 0.5 and removed.

The results showed that the variable human resources had a significant influence on the decision making KPR Xtra Bebas. There are six indicators in the variable human resources, in this study human resources are classified as marketers. The marketer's response in handling consumer complaints is the dominant indicator of consumer decision making. Indent marketer responses with the speed of marketers in answering each question from consumers, where it can be concluded that the dominant indicator in the people variable is related to the process variable, namely the speed of the credit process.

Physical evidence has the influence to stimulate the attractiveness and interest of consumers to find information and make a decision. In the banking world, consumer interest is essential to gain market share. One strategy that is implemented through achievement and appreciation is to get consumer attention. The results of the study show that the physical evidence variable has a significant influence on consumer retrieval. Indicators that have an influence are company achievements and awards. The company's achievements in the consumer credit sector are above the average while the company's awards are as the best brand owners in the mortgage sector. 


\section{Discussion}

Through the results obtained from data analysis can have an impact on the management decisions of Bank X. Managerial implications are a participatory decisionmaking process carried out by a company or how to increase productivity by increasing the capacity, quality, efficiency and effectiveness of existing resources. Managerial implications used are segmentation, targeting, positioning (STP). The segmentation can be determined based on the characteristics of the respondents who have already purchased, namely the income of the most dominant respondents ranging from IDR 5.000.000 to IDR 15.000.000 per month so that the consumers of KPR Xtra Bebas are middle class. The company's target is married consumers. This is consistent with the characteristics of the respondents that the most dominant age range is 27-36 years old who are married and have one or two children. While positioning can create products by consumer desires, namely the speed of the credit process. Managerial implications will be assessed based on three variable mix variables that have a significant effect, namely:

\section{Product}

The results of the study show that product innovation is in line with management's expectations. The product's advantage, which is the decreasing interest rate, provides benefits to consumers and becomes an attraction. However, Bank X needs to evaluate the performance of mortgage business development manager (MBDM) as a business unit that implements Xtra Bebas products. Evaluation results can determine targets that are in line with market share.

2. Human Resources

The development of human capital through continuous training has an impact on personal performance and the team of marketers of KPR Xtra Bebas product. The program for developing the specifications of marketers for both certification, learning development and executive education programs has been excellent. Through the development of specifications, marketers can be more creative in determining marketing strategies.

3. Physical Evidence

Companies should emphasize the determination of physical evidence variables only on company achievements and awards. The company is currently awarded as "The Innovative Home Loan Bank" and "Best Supporting Bank in Property for Excellence Service and Innovative." The company can focus on the mortgage sector by maintaining the award as one of the banks with the proposed KPR product.

\section{Conclusion and Recommendation}

\section{Conclusion}

The results of the study three variables have a significant influence, and four variables do not have a significant effect on KPR Xtra Bebas decision making. The most dominant marketing mix that influences consumer decision making is a mix of human resources. The strategy in the mix of human resources applied by excellent companies is intellectual capital, learning organizations and executive education programs. The decision of consumers to make a decision has a significant influence on the ability of marketers. Marketers are an essential component for companies to develop the KPR business growth. Also, the mix of physical evidence and product mix has a 
significant effect on decision making. The mix of physical evidence indicators that have significant influence is company achievements and awards. The results of the study show that through the "The Innovative Home Loan Bank" award is the attraction of consumers to use KPR Xtra Bebas. The product strategy implemented by Bank X answers management objectives. The superiority of products with declining interest rates is the attraction of consumers to use products. Besides, the company needs to conduct a performance evaluation of the Mortgage Business Development Manager (MBDM). Through performance evaluation, companies can see product growth constraints so that they can determine the appropriate target according to market share. In the three mix variables that have significant influence, they need to be maintained.

\section{Recommendation}

The suggestions that can be submitted for the improvement of similar research in the future are Factors that influence decision making not only consist of seven variables that have been used in this study. Future research can develop new research models using different factors. This study aims to determine the marketing mix strategy to increase KPR Xtra Bebas users to Bank X companies. In future studies can use other products in the same company.

\section{References}

Arpan, K.K. (2010). Pengertian 7 Ps of services marketing. Retrieved from http://download.portalgaruda.org/article.

Chin, W,W. (1998). Partial least square is to LISREL as principal components analysis is to common factor analysis. New York, US: Technology studies.

Engel, J., Blackwell, R.D., Miniard, P.W. (1995). Consumer behavior. 8th ed. Chicago, US: The Dryden Press.

Ghozali, I. (2008). Structural equation model: Metode alternatif dengan partial least square (PLS) Ed. 2. Semarang, ID: Universitas Diponegoro Press.

Hair, J., Bill, B., Bary, J.B., Rudolph, A.E., Rudolp, L.T. (2006). Multivariate data analysis. 6th ed. New Jersey (US): Pearson Prentice Hall.

Hartono, J.M. (2008). Pedoman survey kuesioner : Mengembangkan kuesioner, mengatasi bias dan meningkatkan respon. Yogyakarta,ID: Andi Offset.

Mudrajad, K. (2003). Metode riset untuk bisnis dan ekonomi. Jakarta (ID): Erlangga.

Mustafa, I. (2012). The effect of the central bank lending rate on consumer loan interest rates: an empirical investigation. The Journal of Faculty of Economics and Administrative Sciences 17 (3), 467-474.

Nasution, M.E., Usman, H.M. (2008). Proses penelitian kuantitatif. Jakarta, ID: Fakultas Ekonomi Universitas Indonesia.

Nguyen, T.N., Phan, T.T., Anh, V.P. (2015). The impact of marketing mix elements on food buying behavior. International Journal of Business and Management 10,(10), 206-215.

Nugraheni, A. (2013). Pengaruh bauran promosi terhadap keputusan pengambilan di Rita Pasaraya Wonosobo (thesis). Purworejo, ID: Universitas Muhammadiyah Purworejo.

Putra, P.P. (2017). Analisis pengaruh kualitas layanan, promosi, harga, citra perusahaan dan produk terhadap keputusan pembelian produk asuransi 
kendaraan bermotor di Wilayah DKI (thesis). Yogyakarta, ID: Universitas Gadjah Mada.

Rachmawati, R. (2011). Peranan bauran pemasaran (marketing mix) terhadap peningkatan penjualan (sebuah kajian terhadap bisnis restoran). Jurnal Kompetensi Teknik, 2 (2), 143-150.

Ramadhan, S. (2016). The influence of product mix and promotion mix on purchasing decisions of chocodot. E-Proceeding of Applied Science, 2(2), 458-468.

Ruslan, R. (1999). Manajemen Humas dan Manajemen Komunikasi. Jakarta, ID: PT Raja Grafindo Persada.

Sanja, B. (2017). Expert pricing system as part of marketing mix (dissertation). Bosnia and Herzegovina, BA: University of Mostar.

Sekaran, U. (2003). Metodologi penelitian untuk bisnis. Jakarta, ID: Salemba 4.

Setiawati, H., Hartoyo., Simanjuntak, M. (2018). Analysis on intention of purchasing organic foods by the undergraduate students of IPB using the theory of planned behavior approach. Jurnal Manajemen dan Agribisnis, 15(2), 198-207. http://dx.doi.org/10.17358/jma.15.2.198.

Sibut. (2016). Pengaruh bauran pemasaran terhadap keputusan pembelian ulang konsumen minimarket alfamart di Surabaya. Jurnal Ilmu dan Riset Manajemen, $5(1), 1-23$.

Singh, M. (2012). Marketing mix of 4P's for competitive advantage. Journal of Business and Management (IOSRJBM), 3(6), 40-45.

Solomon, M. (2013). Consumer Behavior. England, US: Pearson Education Limited.

Sriwijayani, T.N. (2008). Pengaruh bauran pemasaran terhadap keputusan konsumen memiliki kartu kredit BRI (thesis). Surakarta, ID: Universitas Sebelas Maret Surakarta.

Steven, W. (2012). Consumer decision making for residential mortgages. Hawai International Conference on System Sciences, 424-1433.

Stephanie, M.T., Eesha, S. (2017). Context-dependent drivers of discretionary debt decisions: explaining willingness to borrow for experiential purchases. Journal of Consumer Research Inc 44(5), 960-973.

Suherman, A. (2006). The effect of marketing mix on participant satisfaction of the binus center training center (thesis). Jakarta, ID: Binus University.

Sumarwan, U., Djunaidi, A., Aviliani, Singgih, H.C.R., Sayono, J.A., Budidarmo, R.R., Rambe, S. (2009). Pemasaran strategik. Jakarta, ID: Inti Prima Promosindo.

Sutiyoso, S. (2018). Evaluasi strategi PT. Asuransi Cigna Indonesia dalam menghadapi persaingan di industri asuransi jiwa Indonesia (thesis). Yogyakarta, ID: Universitas Gadjah Mada.

Supaartagorn, C. (2017). Marketing mix factors toward decision making in the purchasing goods and services via facebook: in the case of muang district, Thailand. International Journal of Management and Applied Science, 3(2), 50-54.

Tjiptono, F. (2008). Strategi Pemasaran. Yogyakarta,ID: PT.Andi Offset.

Utama, J.N., Jawas, A. (2013). Faktor-faktor yang dipertimbangkan konsumen dalam keputusan pembelian laptop merek acer di Kota Denpasar. E-Jurnal Manajemen Universitas Udayana, 2(2), 184-197.

Utami, A.B., Hamid, F.Z., Mawarta, O.S. (2015). Pengaruh harga, pendapatan dan lokasi terhadap keputusan pembelian rumah D'Kranji Residence tahap II Bekasi Barat. Jurnal Manajemen Bisnis, 12(2), 91-97. 
Walangitan, R.J., Wantasen, E., Santa, N.M., Manese, M.A. (2017). Analysis of marketing mix's factors on purchasing decision of UHT (Ultra High Temprature) milk in hypermart Manado Town Square. Journal of Business and Management, 19(8), 64-70.

Zeithaml, V.A, Bitner, M.J. (2000). Services Marketing: Integrating customer focus across The firm second edition. New York, US: McGraw. 